\title{
Communication as an Obstacle for Education: An Analysis on Participation of Hijras in Mainstream Education System of Bangladesh
}

By Md. Ashraful Goni \& Mehnaz Hoque

Bangladesh University of Professionals

Abstract- Hijra is a term given to the intersex, hermaphrodite and, transgender people who are part of the Hijra community in Bangladesh. In 2013 Bangladesh government gave the official recognition of Hijras as a third gender community. But the society still thing Hijras are aliens they are not supposed to live in society and have a life. Though Hijras have official recognition of their sexual identity they are far away to get social recognitio $n$. Educatio $n$ is a basic need for every single person in the world, and education is the best medium of communication to construct the social identity of a person. According to Bangladesh, education policy education is for all. Hijras are also included in the term 'all.' Though they have all the $r$ ight of being a citizen of the people republic of Bangladesh, we never seen a Hijra in school, college, or any other educational institution. Using a qualitative analysis, this study will focus on why Hijras are not participating in the mainstream education system of Bangladesh though they have official recognition as a third gender community. This paper will also focus on the role of society in making this decimation in the education system.

Keywords: hijra, participation, education, communication.

GJHSS-C Classification: FOR Code: 139999

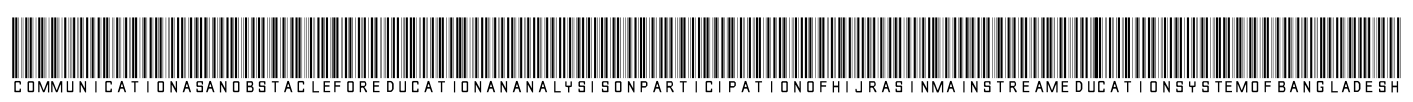

Strictly as per the compliance and regulations of:

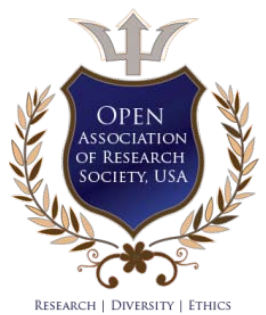

(C) 2020. Md. Ashraful Goni \& Mehnaz Hoque. This is a research/review paper, distributed under the terms of the Creative Commons Attribution-Noncommercial 3.0 Unported License http://creativecommons.org/licenses/by-nc/3.0/), permitting all noncommercial use, distribution, and reproduction in any medium, provided the original work is properly cited. 


\title{
Communication as an Obstacle for Education: An Analysis on Participation of Hijras in Mainstream Education System of Bangladesh
}

\author{
Md. Ashraful Goni ${ }^{\alpha} \&$ Mehnaz Hoque ${ }^{\sigma}$
}

Abstract- Hijra is a term given to the intersex, hermaphrodite and, transgender people who are part of the Hijra community in Bangladesh. In 2013 Bangladesh government gave the official recognition of Hijras as a third gender community. But the society still thing Hijras are aliens they are not supposed to live in society and have a life. Though Hijras have official recognition of their sexual identity they are far away to get social recognition. Education is a basic need for every single person in the world, and education is the best medium of communication to construct the social identity of a person. According to Bangladesh, education policy education is for all. Hijras are also included in the term 'all.' Though they have all the right of being a citizen of the people republic of Bangladesh, we never seen a Hijra in school, college, or any other educational institution. Using a qualitative analysis, this study will focus on why Hijras are not participating in the mainstream education system of Bangladesh though they have official recognition as a third gender community. This paper will also focus on the role of society in making this decimation in the education system. This research paper utilizes the co-cultural theory by Mark Orbe and Muted group theory by Ardener. This study use these theories to understand how social influence is responsible for a minority community to stay out of the mainstream education system. The theories used also helped with explaining the reason how sexual Identity became the main obstacle in the path of education. Keywords: hijra, participation, education, communication.

\section{INTRODUCTION}

$\mathrm{M}$ an, women, and Hijras are humans of the same society, but society has created the gender identity of men and women differently. Till now, society has not given the gender recognition of Hijra people in Bangladesh, though they have an official identity as a third gender according to the law of Bangladesh. When we dig deep to understand this problem, we have found that our education system is the biggest catalyst to construct the gender identity of a human being.

Education is a basic human right for every human being but unfortunately, we don't see third gender people in school though they have all the

Author $\alpha$ : Lecturer, Department of Mass Communication and Journalism, Bangladesh University of Professionals.

e-mail:ashraf.goni@bup.edu.bd

Author o: Lecturer, Department of Mass Communication and Journalism, Jagannath University.

e-mail: rocky.dreamjournalist@gmail.com constitutional right to study into school as their preferred gender or third gender. Create equal opportunities of education for all including any gender identity to establish a society free of discrimination is one aim and objectives of the education policy of Bangladesh.

\section{il. Research Questions}

This research will try to answer the following questions-

1. What is the rate of participation of Hijra people in mainstream education and how educated are they?

2. What are the obstacles they face if they take part in a mainstream education system?

3. Is there any alternative education program available for Hijra people? How many of them want to study farther?

\section{a) Research Gap}

Some dissociated researches on gender sensitivity found in textbooks or in the curriculum of mainstream education in Bangladesh. But No one has done yet no continuous research on this topic. Researchers have discussed only two genders in all these researches. None of them worked on the third gender. They also limited those researches into content analysis only. No research on Hijra population's participation in mainstream education in Bangladesh has d one before.

This study will serve as a primary source of information to future researchers. The recognition of Hijra people as a human largely depends on the awareness of mass people. My research is crucially necessary to increase awareness among people, to ensure human rights of Hijra people and to make the right guidelines for this community.

\section{b) Research limitations}

There some problems and limitations of this research.

1. Interviewing Hijra people was the most challenging task of this research. Many of them did not answer all my questions properly, which may affect the result and this a limitation of my research.

2. Hijra children are often remain hidden in our society. For this reason, I could interview none of them. Those children could have done significant contribution in this study with information. So this was another limitation. 
3. Hijras have complained that the information they provide sold by NGOs to earn money. They keep this in their mind while answering the questions, which increases the chance of getting false or misleading information.

\section{ili. Literature Review}

In the research article titled 'Education of Transgenders in India: Status and Challenges', Dr. Rajkumar (2016) shows that despite the laws in the constitution of India, the other sex (transgender) continues to stigmatize. Transgender people faced discrimination and harassment at family, school and community force them to move to the other places. The nature of the harassment includes verbal, physical and sexual abuse which has a serious impact on the mental health. In a democratic country like India, Transgender has no access to the social and political rights. They are not the part of any welfare scheme. So the researcher suggested for an immense need to intervene at individual, community and policy level to safeguard the rights of transgender.

Md. Ikramul Islam (2016) in, his research `Right To Education of The Third Gender of Bangladesh: An overview shows that -The eunuchs who also known as the third gender is far and beyond the realm of education in Bangladesh. We know the term third gender uses as Hijra in Bangladesh. They have always remained a fundamental part of the Bangladeshi society from ancient time. But unfortunately their present state of existence is reduced to wretched poverty, illiteracy, hatred and mockery. The Hijras are still living in the shadow of rejection from every basic right to equality and education. Our education system is still incompatible for eunuch people of our country. In most of the cases they become the topic for exploration and research for their strange appearances. The government has only given them the right to vote, but they face a desolate future with no access to education. This article describes the steps the authority might take, which for their betterment and to ensure their right to education. To ensure the implementation of human rights and to use the internal capacities of the hijras of our country, we should go forward effectively as early as achievable.

The right to education for the eunuch people is the human rights issue. In Europe, Article 2 of the primary Convention of 20 Walk 1952 to the European Tradition on Human Rights states that the proper to education is recognized as a human right and is caught on to introduce a privilege to education. Concurring to the International Pledge on Financial, Social and Social Rights, the proper to education incorporates the proper to free, obligatory primary education for all, a commitment to create secondary education reachable to all in specific by the illuminated presentation of free secondary education, and an obligation to create legitimate to get justiciable access to higher education in specific by the reformist introduction of free higher education. The right to education moreover incorporates an obligation to supply essential instruction for people who have not completed primary education (http://emmashopebook.com).

"Everyone has the right to education", says Article 26(1) of the 1948 Universal Declaration of Human Rights. Declaration of the Rights of the Child proclaimed by the UN General Assembly in 1959 states, 'they entitle the child to receive education, which shall be free and compulsory, at least in the elementary stages.' From the Geneva Declaration of the Rights of the Child of 1924 to the United Nations Convention on the Rights of the Child of 1989, all international declarations and covenants on rights of the child acknowledge children's right to education (Emma, 1996). It echoes the same in the Dakar Forum on Education for All (EFA) and Millennium Development Goals in 2000. Bangladesh has been trying unremittingly to uphold the cause of education for all since its emergence as an independent country. Article 17 of the Constitution of Bangladesh stipulates that primary education shall be the delicacy of the State. To bear this responsibility, primary education in Bangladesh underwent a great deal of changes and development during the last few years. Bangladesh is a signatory to the world declaration on education for all held at Jomtien, Thailand in March 1990. Bangladesh is also a signatory to the summit of 9 high populous countries held in Delhi. So, as a human being eunuch, people can claim educational right. But practically they are the ignored class of people.

The right to education is crucial to allow eunuch persons to develop to the full of them soon they will include the community. States must guarantee an effective exercise of their right to education in mainstream schools, and/or in special schools only if inclusion in mainstream schools is not possible and if they agree this decision with the parents. This also means that apart from teaching academic skills, education of eunuch people must include grounding for an independent life, adaptive behaviors and social skills. Adult education should provide the utmost range of opportunities and include not only special education or participation in mainstream adult educational programs but also training in basic skills, self-management, living skills, at all ages. Lunch discrimination gratis educational system to ensure basic rights initiatives to introduce formal, informal and technical educations \& create a quota system to enroll hijra in educational institutes and for higher studies in all Universities (Mckeown, 1988).

In Bangladesh, the spirit of the Constitution is to make certain the fortification of fundamental rights of every citizen. Article 27 of the Constitution provides that all citizens are equal before law and may equal 
State shall not discriminate against any citizen on grounds of religion, race, caste or sex (Kelly, 2009). So, as a citizen eunuch, people may definitely get educational right like others. From statistics, there are at least 10,000 hijras in Bangladesh and they are being denied their rights in various sectors including education because of being a marginal group which is inconsistence with the constitution

\section{Theoretical Framework \& Methodology}

This study uses Co-cultural Communication Theory to examine the experiences of Hijra people in the mainstream education system of Bangladesh. Cocultural theory serves as an analytical framework that looks at culture as an uneven site of communicative relations. One of its central assumptions is that it structures societies in hierarchical terms. This creates a dominant position for certain cultural groups while they marginalize other groups (Rubén, 2008). In this research, the researcher focus on how the Hijra or third gender people traditionally marginalized in our mainstream education system. And with the help of the Muted group theory, the research provides insight into the dynamics of the perceptions and experiences of Hijras who sit in silence in the education system of Bangladesh. According to Social anthropologists, Ardener and Ardener advanced the notion of muted group theory based on the observation that there is a dominant group in society and there are groups silenced by the dominant group (Mears et al., 2004). This study draws several phenomenological inquiries that inductively gathered from the in-depth interview from hijra people of Bangladesh.

\section{Data Analysis and Discussion of INTERVIEW}

We have analyzed the data in the light of purpose and question of this research, theoretical framework and selected research method. Co-cultural communication theory and muted group theory have been used to analyze the in-depth interview of Hijras to understand their participation in mainstream education system. We have presented overall result as the answers to research questions.

Here, to analyze the data found from the indepth interviews of 9 people from Hijra community researcher have used the theoretical framework of Cocultural communication theory and muted group theory. Researcher has measured the participation of Hijra people in mainstream education system using some indicators. Those are -

\section{a) Sexual identity is the prime obstacle}

Sexual identity is the largest obstacle for Hijra people to take part in mainstream education. Society have forced many Hijras to drop out from schools just because they are "Hijra", as they do not behave like proper "man" or "woman."

Hijra Anonna (39) said, "My sexual identity was the main problem to get the education. My male classmates have done their masters and doing a good job; female classmates are doing great work or living in abroad. But I'm the only ill-fated Hijra who didn't finish education or to reach my desired goal.'

A person is being deprived of basic rights like education just for his/her sexual identity. From teachers to students, everyone used to misbehave with the Hijra students in schools. Such as nobody wanted to sit beside a Hijra student, verbal bullying and so on. We can define this treatment using muted group theory, as the culture of definitive male-female is the dominant one in our society and they will always try to oppress the culture of sexual minorities.

Another Hijra, who has received no education at all, HijraMunni (23) said, "I could not study because I am Hijra. They wouldn't let me sit in class. I've always had the confusion of whom to sit with, boys or girls? If I sit beside boys, they would say that I was a girl. If I sit beside a girl, they would say I was a Hijra. They used to taunt me a lot. So much that I had to quit school in just a few days."

Hijra Kajol (28) was saying, 'I couldn't go to school because I was Hijra. Classmates used to misbehave. Therefore, I couldn't study.'

According to Hijra Choto (23), "I am Hijra. Both boys and girls used to tease me if I sit beside them. Where would I sit then? Even my teacher used to tease me saying why am I like this. But he never understood I differed from others. And this continued for a while, and then I left school. I cannot study in a place where everyone teases me."

Hijra people are being mistreated for their sexual identity for a long time now. Everyone in school used to avoid them. Like other boys and girls, education is a basic right for Hijra people. But the dominant men and women of the society is keeping them away for their basic rights.

Hijra Kotha (27) said, 'I used to get ignored by my classmates. Some would say they wouldn't sit beside a girlish boy like me. I didn't understand what they meant properly, but I felt bad. And after some time, I had to leave school because of this.'

Hijra Khushi (26) was saying, 'I was too poor to study, still used to go to a government school. I used to always mix up with girls and went to school with them, sit beside them. Boys used to disturb me by asking why I am always with girls or behave girly. They called me half ladies. At some point, I couldn't bare anymore and left school.'

To summarize all these statements, sexual and social identities and their behaviors were the biggest problem for Hijra people to take part in mainstream 
education system. We can define these using Cocultural communication theory as the dominant gender culture of our society keeps Hijra people away from mainstream education. Also, using the muted group theory, we can say that, dominant gender of our society, precisely men are making an environment for Hijra people to leave mainstream education system and eventually leave schools.

\section{b) Society Harassed Hijra People}

Teacher and classmates often harasseHijra student in the School. Sometimes this extends to sexual harassment. Society is very much concern about eve teasing with girls, for Hijra people it is very common. Some terrible stories unfold upon asking for the harassing experience Hijra people faced in schools.

Hijra Anonna (39), working in Bondhu Social Welfare Society, said, 'A Hijra person doesn't understand what she is at the young age. Everyone from teacher to classmates makes her understand that she is a sexual minority, she doesn't belong to school, she belongs to street, what she will study in school? Society won't give you validation. Ultimately, you got to be in the streets, begging for money. So there's no point of studying. Entire society uses the word Hijra as a slang.'

Sexual harassment is a lifelong scar for anyone. Women give up workplace, family or even society being the victims of sexual harassment. Hijra students cannot tell anyone about their sexual harassment since society consider them as 'male' in our society. Dominant gender group of society oppresses sexual minorities like that to keep them away from mainstream society.

Hijra Kajol (28) was saying her terrifying experiences, 'I was in class six that time. One day some 4-5 classmates got me in the toilet and wanted to see exactly what I am. They harassed me sexually that day. I was in a terrible place but couldn't tell anybody. Who would take seriously that a boy got harassed in school?'

Verbal abuse was also a common phenomenon alongside sexual harassment. They get insulted every day. Since the word 'Hijra' itself is a slang in our society, it is no big deal shaming Hijra people for their sexual orientation. They get shamed for not behaving properly like a 'man' or 'woman', which we can consider as the 'standard' in our male dominant society.

Hijra Joya (24) was saying, 'I used to study in a boys' school. There was no problem until I was in class five. Problems started when my women-like features became visible. It wasn't sexual harassment, but more like stigmatizing me for my behaviors. They used to call me bitter names like half-ladies, girly boy, etc. I felt so bad and asked myself if I really am different from them. What if I belong to a different society?'

Another Hijra person, Hijra Bithi (18) said, 'They used to tease me with all the dirty words. Even my teacher used to harass me if I did not submit my homework. He would say things like dancing in front of the class or to sing a song. They used to make fun of me, and I couldn't take it easy."

Our male dominant society was not happy just abusing them verbally or physically. Showing physical force is the ultimate way to dominate over someone. And they did exactly that. Male students in schools beat those Hijra students.

Hijra Choto (23) was saying, 'Boys used to throw stones at me. They wouldn't take me to play cricket with them. They didn't let me sit with them to have tiff in saying I am Hijra, I cannot sit with them. Both girls and boys treated me the same way. My teacher used to beat me for behaving like girls.'

From all this discussion above Hijra people face a tremendous amount of harassment to take part in mainstream education system, such as, stigmatizing, teasing, sexual harassment. In the light of muted group theory, we can say that dominant gender group creates an environment of harassment for the weak and minor gender group so they steer away from social institutions like school and thus the dominance continues.

\section{c) Hijra people have no alternative option to take education \\ It should be natural to have an alternative} education system for Hijra people since they cannot do so in mainstream system. But unfortunately there is not any such institution. For instance, there are specialized schools for special needs children, but none for Hijra children. Also, there is no adult education system for Hijra people either.

Hijra Kotha (40) was saying, 'There is no school for Hijra people. Though government has said they will give some money to Hijra children for education expenses. That means government will provide special scholarship to Hijra children so they can continue their study. But till now there is no attempt to open a specialized school for them. Neither from government nor from NGOs.'

Hijra Khushi (26) said, 'I've never seen such thing in my entire life. I've been active in this community for like 10-12 years but seen nothing like that. I cannot even rent a house and open a schools for us.'

Hijra Munni (23) said, 'There is no separate school for Hijra children. No government or NGO haven't been able to provide us such a facility.'

Hijra Joya (24) was saying, 'There is no such school for Hijra children to exist in our country. There are special schools for transgender people in foreign countries. They build those schools for them.'

There are no alternative schools for Hijra children and for adults. Adult education program is running on many parts of our country, but none for Hijra people. Different NGOs in Bangladesh provide them different facilities but not adult education.

Upon asking on the availability of an adult education program for Hijra people, HijraAnonna (39) 
was saying, 'Some NGOs provide HIV awareness program, sex education, mental and physical health programs but no formal education program for us. Government has taken no steps either. In Bangladesh there's no scope for adult education for Hijra people.'

Hijra Kajol (28) was saying, 'There's no way I can take an education at this age. I couldn't study when I was a child, neither I have any scope now. There is no such school for Hijra people of my age.'

From the discussion above we can see there is no alternative education program available for Hijra people. They cannot study in schools neither in young age nor there is any school for them after being an adult. We can define this using muted group theory as a dominant gender group like men are making them stay out of school and the communication among these powerless group of people are being controlled and behaviors are being imposed on them by the dominant group.

d) Less educational qualification yet eager to be literate

During the literature review for this research we have seen that rate of literacy is very low among Hijra people. We have taken an in-depth interview of nine Hijra persons for this study and only two (Ananna and Kotha) of them have passed Higher Secondary (HSC). Rest of them could not continue to study more than $8^{\text {th }}$ grade. Munni did not receive any education at all. She cannot even write her name. We cannot make literacy percentage among Hijra people since researcher did not do any survey here. But from the data of interviews, we can say that the percentage is very low. One more notable point is, despite the low literacy rate Hijra people Hijra's are egger to be literate.

Hijra Choto (23) was saying, 'I've studied till class eight and wanted to go farther. I will study again if I have given a chance.'

Hijra Nodi (19) saying, 'I studied till class seven and wanted to do more because of all the mocking from boys. I left that place cause nobody liked me there. They forced me to leave.

Those who have passed HSC are in a better place than others. They don't have to beg on streets or be sex workers. But they wanted to study more. Pressures from society and lack of family support was the main culprit for them to be in darkness. But they believe that they have the potential to be a national asset by educating themselves if the society gave them a chance.

Hijra Anonna (39) was saying, 'I have passed my HSC. But I, Anonna, believe that I am not literate at all. I didn't get any facilities to study. But now if I had time to study in a university I hope I would do good. There are so many like me who have passed secondary or higher secondary but couldn't go farther. If government could ensure a warming environment for us to study, I'm sure there wouldn't be so much of us uneducated. We don't want to be the burden of society, rather we want to be an asset. We have that ability and courage. Just give us a chance to grow up.'

Hijra Kotha (40) was saying, 'I've studied till HSC by my willpower and courage. I wanted to be a doctor. But family society; nobody helped me. My willpower wasn't enough, and I had to drop out. Then I got separated from my family. I used to learn to dance and was a listed dancer in Shilpokola Academy. I got involved with those cultural activities and eventually gave up studying.'

We can define these statements using Cocultural communication theory and muted group theory as the dominant class of our society negatively influences this powerless community of people of their mind setup of taking education. These results huge drop out rate against their will. Thus the literacy rate stays low. In short, uneven distribution of resources and unfair implementation of force from the dominant class is the main reason of a low percentage of literacy among Hijra people.

\section{e) Hijra people have their own idea of an education system}

As answers to the question of how Hijra can be a part of our mainstream education system, they have given some different ideas. All of them believes a change of perspective in society and government efforts like: specialized school, adding lessons about Hijra people in textbook among others will help them take part in mainstream education system.

Hijra Kajol (28) said, 'If they gave us a separate school and colleges we could have continue studying even after leaving our families, as we have something to hold on to.'

Hijra Munni (23) said the same, 'It will be a helpful if we get a specialized school. We could study well then.'

Hijra people understand that there is no alternative of education to improve their lives. At the same time they hope for help from both government and mass people. Government has to take efforts and people in our society need to change their perception to Hijra persons. Hijra people gave some ideas to implement these.

Hijra activists Anonna (39) was saying, 'Government has no magic wand that can change the situation overnight. First, we need to work on minimizing the distance between us and other people through heavy campaigning. We need to aware people in every sector of the government system. Along with that, to ease to life of next generation we can add a chapter in the primary education discussing the life and culture of Hijra people. If we can educate mass people from the elementary level, we will change the situation in a good way in next $10-20$ years.' 
Hijra Khushi (26) was saying, 'To improve the lifestyle of newborn Hijra children we need to convince our civil society to look at them as a general human being. Ensuring them a proper education. Government gave us some rights, but we cannot use them. Only giving rights aren't enough, they get to implement those.'

Hijra Kotha (40) said, 'Teachers in school should know about the rights given by the government for Hijra people, so that those who need the right can claim. There should be an option to register Hijra children as a separate gender from male or female in the school admission form. That will minimize the hassle for the guardians of Hijra children.'

If we analyze these statements with Co-cultural communication theory and muted group theory, we can say that dominant gender class has gagged the voice of Hijra people by forcefully implementing a communication system that even eventually makes them leave mainstream society. But now, if these dominant gender class helps the Hijra community then they will be no more a muted group. Rather, they have the potential to become an important part of the society.

\section{Vi. Recommendations to Associate Hijra People with Mainstream Education System}

Many people from Hijra community have given their different ideas on how we can associate them into the mainstream education system. Here's a list of recommendations for associating Hijra Population into mainstream education.

1. We need to change our perception towards Hijra people. We have to remember, Hijra people are human being like ourselves. Their sexual identity differs from men and women. We should acknowledge that and protect them from the social harassment.

2. We need specialized schools for Hijra children and adults. We need to implement The Hijra development Act to ensure their safety and development.

3. We can include a chapter or a story of Hijraculture in primary level textbooks so that all children can know about these people. That will help to change the perception towards Hijra people positively.

4. There should be an option to register third gender in any educational institution's admission form, so that teachers will have a clear idea about students sexual orientation.

5. Government should launch a campaign and other social events to minimize the distance among Hijra people and mass population .

6. The government can take steps to educate Hijra children about sensitive topics like eve teasing, sexual harassment, etc. So they can claim legal help in need.

7. Hijra rights must not stay limited into pen and paper, rather government has to take efforts to implement them.

\section{Vil. Conclusion}

The research found that Hijra people have next to no participation in mainstream education in Bangladesh. They cannot continue to study much longer because of their sexual orientation. And through this the society marginalized them and make them deprived from basic right like education just because they are Hijra (third gender). Teachers, students and every other citizen of society believe that schools are not for Hijra people and this dominance ideology of the society eventually makes Hijra community invisible. Without the right to education it will be difficult for them to survive with respect, dignity and generous life. As a result, they leave schools; they leave society and start living on their own. But the situation is changing slowly. Now the people of the third gender should be positively welcome in the society, media is trying to create their presence in our society; and the government, the civil society and the Non-Governmental Organizations should stand by them through ensuring their rights to education. And the assurance of right to education to the Hijras (third gender) may support and preserve the image of liberal Bangladesh.

\section{BiBLIOGRAPHY}

1. AthreyeViji. The Life of Transgender in India retrieved from www.mapsofindia.com/my-india/ goverment/the-life-of-transgenders

2. Emma, W. (1996). Sexuality and the Reading Encounter: Identity and Desire in Proust, Duras, Tournier, and Cixous (ISBN 0-19-815885-8). Oxford: Oxford University Press

3. http://emmashopebook.com/en/e-book/295334/ education-inequality-and-global-justice (Retrieved on 26.08.2015)

4. http://www.dhakatribune.com/law-rights/2014/oct/ 25/Hijras-demand-proper-recognition-thirdgender\# sthash.ELWm4uoz.dpuf (Retrieved on 17.06.2015)

5. http://www.dhakatribune.com/op-ed/2013/nov/17/ third-gender (Retrieved on 12.06.2015)

6. http://www.thedailystar.net/advancement-of-trans gender-rights-55529 (Retrieved on 10.08.2015)

7. Islam, Akramul (2016), Right To Education of The Third Gender of Bangladesh: An overview, IOSR Journal Of Humanities And Social Science (IOSRJHSS) Volume 21, Issue 9, Ver. 7 (Sep. 2016) PP 29-34 e-ISSN: 2279-0837, p-ISSN: 2279-0845.

8. Kelly, R. C. (2009). Moving Across and Beyond Boundaries. Duke University Press, 15 (4): 646-648 
9. Mckeown, T. (1988). The origin of human disease (2nd edition). Blackwell Publishers, England

10. Newspaper Indian Express (2014). Reserved seats for transgender children in school retrieved from www.indianexpress.com/cities/Delhi

11. Rajesh and MD Aslam Naved (2013). Approach Paper on Education and Employment opportunities \& Challenges for Transgender. Ministry of Social Justice and Empowerment Government of India retrieved from www.socialjustice.nic.in/pdf/ appendix5

12. Rajkumar, Dr. (2016), Education of Transgenders in India: Status and Challenges, International Journal of Research in Economics and Social Sciences (IJRESS), Vol. 6 Issue 11, November - 2016, pp. 15 24 ISSN(0): 2249-7382

13. Rubén Ramírez-Sánchez (2008). Marginalization from Within: Expanding Co-cultural Theory Through the Experience of the Afro Punk, Howard Journal of Communications, 19:2, 89-104, DOI: 10.1080/10646 170801990896

14. Satashivam. P (2012). Rights of Transgender People: Sensitising Officers to Provide Access to Justice.http://www.hcmadras.tn.nic.in/jacademy/Arti cle/PSJ-CJO-SPEECH-Royappetah.pdf

15. Wijngaard, V. D. and Marianne (1997). Reinventing the Sexes: The Biomedical Construction of Femininity and Masculinity. Indiana University Press. 